\title{
WOJSKOWI I POLITYKA W AMERYCE ŁACIŃSKIEJ NA PRZEŁOMIE XX I XXI WIEKU
}

\author{
MILITARY AND POLITICS IN LATIN AMERICA AT THE TURN \\ OF THE 20TH AND 21ST CENTURIES
}

Michał Stelmach* (ㅇ

Celem artykułu jest analiza nowych form militaryzmu i politycznej aktywności wojskowych w państwach Ameryki Łacińskiej na przełomie XX i XXI wieku. Poddaję analizie trzy wybrane formy udziału wojkkowych w polityce. Rozpoczynam od uwag na temat interwencjonizmu wojskowego. Następnie skupiam się na fenomenie wojskowego prezydencjalizmu, czyli udziału $\mathrm{w}$ wyborach prezydenckich i pełnienia funkcji konstytucyjnych prezydentów przez byłych wojskowych, którzy w przeszłości łamali porządek konstytucyjny, inspirując i/lub przeprowadzając zamachy stanu lub sprawując dyktatorską władzę, a także łamali prawa człowieka w okresie dyktatur i wewnętrznych konfliktów zbrojnych. W dalszej kolejności badam problem militaryzacji partii politycznych, wskazując na zaangażowanie byłych wojskowych w tworzenie nowych partii politycznych reprezentujących interesy środowiska lub też zasilanie przez byłych wojskowych już istniejących partii politycznych.
\end{abstract}

The article aims at analysing new forms of militarism as well as a political activity of servicemen in Latin American countries at the turn of the $20^{\text {th }}$ and $21^{\text {st }}$ centuries. The article analyses three selected forms of military participation in politics. Firstly, it focuses on the military interventions. Secondly, it analyses a phenomenon of military presidentialism - former servicemen who, having broken the constitutional order inspiring and/ or carrying out coups or exercising dictatorial power and having violated human rights during the period of dictatorships and internal armed conflicts, participate in presidential elections and serve presidential function. Thirdly, the author investigates the question of militarization of political parties, demonstrating involvement of former servicemen in creation of new political parties representing milieu interests or former servicemen joining political parties.

* Uniwersytet Łódzki, Wydział Studiów Międzynarodowych i Politologicznych. 
Słowa kluczowe: wojskowi; polityka; militaryzacja polityki; Ameryka Łacińska
Keywords: military; politics; militarization of politics; Latin America

\section{WSTĘP}

Celem artykułu jest analiza nowych form militaryzmu i politycznej aktywności wojskowych w państwach Ameryki Łacińskiej na przełomie XX i XXI wieku. Stawiam tezę, że od lat 90. XX wieku w Ameryce Łacińskiej równolegle do procesów demokratyzacji i ustanawiania demokratycznej kontroli nad siłami zbrojnymi systematycznie postępuje proces militaryzacji polityki. Siły zbrojne jako instytucja stanowią wciąż ważny, choć już nieformalny ośrodek władzy, a przynajmniej potężną i wpływową grupę nacisku, natomiast wysocy oficerowie, zwłaszcza w stanie spoczynku, aktywnie uczestniczą w życiu społeczno-politycznym swoich państw, pełniąc role liderów i członków partii politycznych oraz przywódców. Fenomen sprawowania najwyższego urzędu w państwie przez byłych wojskowych definiuję jako wojskowy prezydencjalizm.

Współczesny militaryzm w Ameryce Łacińskiej nie jest zjawiskiem jednorodnym. Zaangażowanie wojskowych w politykę przybiera rozmaite formy i różni się stopniem nasilenia w poszczególnych regionach i państwach. W odróżnieniu od aktywności politycznej wojska w drugiej połowie XX wieku, obecnie ma w większym stopniu charakter personalny niż instytucjonalny. Badacze odchodzą od przyjętej na początku lat 90. terminologii, rezygnując $z$ ukutego wówczas pojęcia „wojska polityczne” na rzecz nowego, lepiej oddającego współczesne realia sformułowania „politycy w mundurach”. Wojsko jako instytucja, mając świadomość ograniczonych możliwości działania, chociażby z racji uwarunkowań międzynarodowych, stara się unikać przeprowadzania zamachów stanu i sprawowania bezpośredniej władzy. Nie oznacza to jednak, że całkowicie porzuciło interwencjonizm $\mathrm{w}$ formie zamachu stanu i zrezygnowało $\mathrm{z}$ pełnienia roli arbitra politycznego, co potwierdzają wydarzenia w Hondurasie w 2009 r.Współczesny militaryzm należy postrzegać jednak przede wszystkim jako formę organizacji władzy państwowej, w której siły zbrojne, ich dowódcy bądź emerytowani wojskowi, wciąż powiązani ze środowiskiem, pośrednio i w sposób nieformalny wywierają decydujący wpływ na politykę państwa, de facto dominując nad instytucjami cywilnymi, mimo obowiązywania regulacji prawnych, ustanawiających cywilne zwierzchnictwo nad siłami zbrojnymi. 
Z uwagi na obszerność i złożoność problematyki w artykule poddaję analizie trzy wybrane formy udziału wojskowych w polityce, które w mojej ocenie zasługują na szczególną uwagę. Rozpoczynam od uwag na temat instytucjonalnego interwencjonizmu. Następnie przechodzę do analizy fenomenu wojskowego prezydencjalizmu, czyli udziału w wyborach prezydenckich i pełnienia funkcji konstytucyjnych prezydentów przez byłych wojskowych, którzy w przeszłości łamali porządek konstytucyjny, inspirując i/lub przeprowadzając zamachy stanu lub sprawując dyktatorską władzę, a także łamali prawa człowieka w okresie dyktatur i wewnętrznych konfliktów zbrojnych. W dalszej kolejności badam problem militaryzacji partii politycznych, wskazując na zaangażowanie byłych wojskowych w tworzenie nowych partii politycznych reprezentujących interesy środowiska lub też zasilanie przez byłych wojskowych już istniejących partii politycznych. Wśród innych form i przejawów współczesnego militaryzmu w Ameryce Łacińskiej, które na potrzeby niniejszego artykułu wyłączam $\mathrm{z}$ rozważań, należałoby wskazać m.in. wywieranie presji na rządzących poprzez stowarzyszenia kombatanckie, akty nieposłuszeństwa, polegające m.in. na niewykonywaniu rozkazów pacyfikacji manifestacji, wydawanych przez prezydentów czy też udział w debatach publicznych i politycznych.

Badanie wymiarów i form militaryzacji polityki w Ameryce Łacińskiej jest procesem złożonym i trudnym przede wszystkim $z$ uwagi na brak metod badawczych pozwalających zmierzyć faktyczny wpływ sił zbrojnych i wojskowych (korpusu wysokich oficerów) na procesy polityczne w państwach regionu. W literaturze podejmującej problematykę stosunków cywilno-wojskowych spotykamy się z mało precyzyjnymi sformułowaniami, określającymi wpływ armii jako duży, średni, znikomy, minimalny bądź żaden, które są najczęściej subiektywnymi ocenami i opiniami badaczy i analityków.

Dla realizacji celu artykułu, uwzględniając niedostatek innych metod wykorzystywanych w naukach politycznych, oparłem się na metodzie analizy instytucjonalno-prawnej. Metoda ta pozwala analizować pozycję i rolę sił zbrojnych oraz ich członków w systemie politycznym, określić formalnoprawny status relacji pomiędzy sferą cywilną a wojskową, jak również daje możliwość odwoływania się do historii, dzięki czemu można prześledzić zmiany w stosunkach cywilno-wojskowych. W ograniczonym zakresie wykorzystałem także metodę empiryczną. Obserwacja postaw i zachowań wojskowych, ich wypowiedzi pozwoliła skonfrontować stan prawny oraz deklaracje wojskowych i „polityków w mundurach" z realiami panującymi w państwach latynoamerykańskich. 


\section{INTERWENCJONIZM WOJSKOWY W AMERYCE ŁACIŃSKIEJ NA PRZEŁOMIE XX I XXI WIEKU}

W okresie 1990-2015 w Ameryce Łacińskiej władzę przed upływem kadencji straciło dwudziestu prezydentów. Dziewiętnastu z nich złożyło urząd z zachowaniem procedur konstytucyjnych, $\mathrm{w}$ drodze impeachmentu, ustępując pod presją polityczną, a niekiedy masowych protestów społecznych. Należy podkreślić, że w Ameryce Łacińskiej wojsko nie interweniowało w obronie prezydentów i nie przerwało żadnej procedury impeachmentu od ponad 15 lat. Siły zbrojne nie uchroniły przed impeachmentem np. prezydentów Brazylii, Collor de Mello (1992 r.) i Dilmy Rousseff (2016), Boliwii - Gonzalo Sancheza de Lozady (2003) i Carlosa Mesy (2005), Peru - A. Fujimoriego (2000) r., i Pedro Kuczynskiego (marzec 2018), Argentyny - Fernando de la Rua (2001), i co bardziej znamienne - nie wystąpiły w obronie swojego kolegi, gen. Otto Pereza Moliny, który we wrześniu 2015 r. złożył urząd prezydenta Gwatemali w związku z postawionymi mu zarzutami udziału w grupie przestępczej, biernego łapownictwa i oszustw podatkowych (afera „La Linea”).

Nie oznacza to jednak, że w ostatnich dekadach siły zbrojne wyłącznie biernie przyglądały się wydarzeniom politycznym. Na przełomie XX i XXI wieku duchy interwencjonizmu odżywały w Ameryce Łacińskiej kilkukrotnie. Pierwsza fala protestów i puczów wojskowych miała miejsce w pierwszym okresie transformacji, jeszcze w latach 80. i 90. XX wieku. Wojskowi podejmowali wówczas akcje zbrojne przeciwko rządzącym w Argentynie i Chile w 1990, 1993 i 1995 r., pokazując swoje niezadowolenie $\mathrm{z}$ kierunku reform $\mathrm{w}$ sektorze obrony oraz prób ograniczania autonomii sił zbrojnych i pociągnięcia do odpowiedzialności oficerów odpowiedzialnych za łamanie praw człowieka w okresie wojen i dyktatur. Na początku XXI w. wojskowi również manifestowali swoje niezadowolenie, organizując protesty i pucze. Do największych wstrząsów dochodziło w Boliwii (2003), Ekwadorze (2000 i 2005), Wenezueli (1992 i 2002) i Peru (2000 i 2005; Kruijt, 2012).Wszystkie te wystąpienia wojskowych należy traktować jako akcje polityczno-wojskowe, które mogły doprowadzić do obalenia legalnych rządów. Jednak tylko zamach w Wenezueli w 2002 r. zakończył się sukcesem, przy czym krótkotrwałym. Do 2009 r., kiedy to władzy pozbawiony został prezydent Hondurasu Manuel Zelaya, zamachy stanu były w Ameryce Łacińskiej w zasadzie nieobecne. W Hondurasie wojsko, wykonując polecenia Sądu Najwyższego, wkroczyło do pałacu prezydenckiego, zmusiło prezydenta do podpisania rezygnacji i wyjazdu z kraju (Cálix, 2010). Nie wchodząc w uwarunkowania i przebieg kryzysu politycznego, ani też 
nie rozstrzygając o racjach i winach stron, należy stwierdzić, że wojsko, które co prawda przekazało władzę przewodniczącemu Kongresu (zgodnie z konstytucją), ponownie zaistniało w polityce jako kluczowy aktor i instrument służący rozwiązywaniu konfliktów politycznych. Przewidzianą konstytucją procedurę impeachmentu, także decyzją cywilnych polityków, zastąpiono polityką siły.

\section{NOWE PRZEJAWY MILITARYZMU}

Podzielam pogląd Dawida Pion-Berlina (2008b, 2017), że niewystępowanie albo sporadyczne występowanie wojskowych zamachów stanu wcale nie oznacza ustanowienia cywilnego zwierzchnictwa nad siłami zbrojnymi, a tym bardziej nie oznacza wycofania się wojskowych z polityki. Siły zbrojne nauczyły się wykorzystywać autonomię instytucjonalną i polityczną, jakie im zagwarantowano w okresie tranzycji, i poruszając się w obrębie swoich uprawnień konstytucyjnych i ustawowych w nowy sposób oddziałują na politykę na różnych szczeblach. W niniejszym artykule poddam analizie dwie spośród rozlicznych form zaangażowania wojskowych w politykę: 1) pełnienie przez nich funkcji prezydentów; 2) aktywność w partiach politycznych.

\section{WOJSKOWY PREZYDENCJALIZM CZYLI PREZYDENCI W MUNDURACH}

W latach 90. i pierwszej dekadzie XXI wieku prezydentami w wielu państwach Ameryki Łacińskiej zostali wybrani byli dyktatorzy lub oficerowie sił zbrojnych, organizatorzy nieudanych zamachów stanu, którzy zrzucili mundury i rozpoczęli działalność polityczną (Montecinos, 2010). W państwach regionu odrodził się mit caudillo - silnego, charyzmatycznego przywódcy wywodzącego się z kręgów wojskowych, a przynajmniej w znacznym stopniu z nimi powiązanego. W 1997 r. wolą narodu, wyrażoną w akcie wyborczym, do władzy w Boliwii powrócił Hugo Banzer (Acción Democrática Nacionalista, ADN), sprawujący dyktatorską władzę w latach 1971-1978. W 1998 r. wybory prezydenckie w Wenezueli wygrał kandydat Movimiento V República (MRV), Hugo Chávez Frias - dowódca puczu z 1992 r., którego celem było obalenie prezydenta Carlosa Andrésa Péreza. W 2002 r. prezydentem Ekwadoru wybrano emerytowanego wojskowego Lucio Gutierreza (Partido Sociedad Patriótica, PSP), który w styczniu 2000 r. 
uczestniczył w rebelii zorganizowanej przez ludy tubylcze i niższych rangą wojskowych, w wyniku której władzę utracił konstytucyjny prezydent Jamil Mahuad. W Peru w 2006 r. w wyborach prezydenckich omal nie zwyciężył ppłk. Ollanta Humala (przegrał z Alanem Garcią), który wspólnie z bratem Antauro i ruchem etnokaserystycznym ${ }^{1}$ pod koniec 2000 r. zorganizował akcję zbrojną polegającą na samowolnym opuszczeniu bazy wojskowej w sprzeciwie wobec trwającej od lipca 2000 r. trzeciej kadencji A. Fujimoriego. Próbowano także powiązać go z kolejną akcją zbrojną podjętą przez brata w 2005 r., wymierzoną w prezydenta Alejandro Toledo, ale nie znaleziono dostatecznych dowodów. Co ciekawe, Ollanta Humala w sierpniu 2006 r. został oskarżony o naruszenia praw człowieka, w tym stosowanie tortur i morderstwa, w trakcie służby wojskowej w czasie walk z bojownikami ze Świetlistego Szlaku. Zaprzeczył stawianym mu zarzutom. Konsekwentnie odwołując się do sektorów wykluczonych, ale łagodząc znacznie retorykę, wygrał wybory w 2011 r., stojąc na czele własnej formacji politycznej - Partido Nacionalista Peruano (PNP; Pietraszczyk-Sękowska, 2014). W 2010 r. sukces wyborczy odniósł w Surinamie płk. D. Bouterse, lider Partido Nacional Democrático (NDP), który dwukrotnie przewodził zamachom stanu - w 19980 i 1990 r. i sprawował dyktatorską władzę w latach 1980-1988 oraz 1990-1991, a dodatkowo ciążą na nim zarzuty bliskiej współpracy z kartelem z Medelin. W 2011 r. w Gwatemali najwyższy urząd w państwie objął emerytowany wojskowy, gen. Otto Perez Molina i jego partia - Partido Patriota, silnie związana ze środowiskiem wojskowych, który podczas kampanii obiecywał „rządy twardej ręki”, pokój i bezpieczeństwo (Stelmach, 2016). Generał Perez Molina był pierwszym od czasu formalnego zakończenia dyktatury w $1986 \mathrm{r}$. emerytowanym wojskowym, który został prezydentem Gwatemali. W 2018 r. w Brazylii wybory prezydenckie wygrał Jair Messias Bolsonaro, emerytowany wojskowy (w stopniu kapitana), który obejmie urząd w styczniu 2019 r.

Tabela 1. Wojskowi w stanie spoczynku sprawujący urząd prezydenta w państwach Ameryki Łacińskiej w okresie 1997-2018

\begin{tabular}{|c|c|c|c|}
\hline Prezydent & Państwo & Kadencja & Partia polityczna \\
\hline gen. Hugo Banzer Suárez & Boliwia & $1997-2001$ & Acción Democrática Nacionalista \\
\hline płk. Hugo Rafael Chávez Frías & Wenezuela & $1999-2013$ & $\begin{array}{c}\text { Movimiento V República Partido } \\
\text { Socialista Unido de Venezuela }\end{array}$ \\
\hline
\end{tabular}

1 Grupa nacisku; ruch odwołujący się do weteranów konfliktu wewnętrznego rozczarowanych rządami fujimorystów. 


\begin{tabular}{|c|c|c|c|}
\hline Prezydent & Państwo & Kadencja & Partia polityczna \\
\hline $\begin{array}{c}\text { płk. Lucio Edwin Gutiérrez } \\
\text { Borbúa }\end{array}$ & Ekwador & $2003-2005$ & Partido Sociedad Patriótica \\
\hline $\begin{array}{c}\text { płk. Ollanta Moisés Humala } \\
\text { Tasso }\end{array}$ & Peru & $2011-2016$ & Partido Nacionalista Peruano \\
\hline $\begin{array}{c}\text { płk. Desiré Delano } \\
\text { (Dési) Bouterse }\end{array}$ & Surinam & $2010-$ nadal & Partido Nacional Democrático \\
\hline gen. Otto Perez Molina & Gwatemala & $2012-2015$ & Partido Patriota \\
\hline kpt. Jair Messias Bolsonaro & Brazylia & $2019-$ & Partido Social Liberal \\
\hline
\end{tabular}

Źródło: opracowanie własne.

Warto wspomnieć również o niespełnionych ambicjach i niezrealizowanych planach zdobycia władzy w swoich krajach przez wojskowych w stanie spoczynku. W Paragwaju, mimo obowiązywania konstytucyjnego zakazu startu w wyborach osobom zaangażowanym w zamachy stanu, aspiracje do objęcia najwyższego urzędu w państwie przejawiał gen. Lino Oviedo. O ile nie zezwolono mu na start w wyborach w 1998 r., o tyle już w 2008 r. wystartował z rekomendacji Partido Colorado (PC). Uzyskał 22\% głosów, przegrywając z Fernando Lugo i Blancą Ovelar (Kruijt, 2012; Kruijt, Koonings, 2002). W Gwatemali, mimo że konstytucja wyraźnie zakazywała (i nadal zakazuje) ubiegania się o urząd prezydenta osobom, które dokonały zamachu stanu, Trybunał Konstytucyjny po tym, jak kraj przeżył największy kryzys polityczny od czasów wojny domowej (masowe i gwałtowne protesty inspirowane przez Montta) i z obawy przed możliwym zamachem stanu, zaakceptował w 2003 r. kandydaturę Riosa Montta odpowiedzialnego za organizację i przeprowadzanie masakr na ludności indiańskiej w okresie wojny domowej² . Należy podkreślić, że mimo niepowodzenia w wyborach prezydenckich Rios Montt do śmierci pozostawał znaczącą postacią na gwatemalskiej scenie politycznej, będąc liderem (nieformalnym) Frente Republicano Guatemalteco (FRG), a od 2013 r. Partido Republicano Institucional (PRI), w latach 200-2004 pełniąc natomiast funkcję przewodniczącego Kongresu (4 kadencje) ${ }^{3}$. Generał de facto przejął ważniejszą część obowiązków cywilnego

2 Pierwszą próbę startu gen. Riosa Montta w wyborach prezydenckich zablokowano w $1996 \mathrm{r}$. Były to pierwsze wybory po zakończeniu wewnętrznego konfliktu zbrojnego, a czwarte od 1986 r., kiedy to siły zbrojne przekazały władze cywilom.

3 W 2015 r. w wyborach prezydenckich, wbrew zapisom konstytucji, udział wzięła córka byłego dyktatora, Zura Ríos Sosa, której kandydatura została zatwierdzona przez Sąd Najwyższy i Trybunał Wyborczy. 
prezydenta Portillo, zapewniając sobie wpływ na nominacje wojskowe oraz koordynację prac gabinetu prezydenckiego (Kruijt, 2012; Booth, Wade, Walker, 2014; Stelmach, 2016).

Wkroczeniu wojskowych na scenę polityczną w państwach Ameryki Łacińskiej sprzyjało kilka czynników. Po pierwsze kryzys instytucji reprezentujących społeczeństwo, w tym głównie tradycyjnych partii politycznych. Hugo Chávez i Lucio Gutierrez przejęli elektorat odpowiednio Acción Dmeocratica i Izquierda Democratica, które głosząc hasła neoliberalne, odeszły od swojego elektoratu (Montecinos, 2010). W 2006 r. Ollanta Humala przejął część elektoratu Partido Aprista Peruano (APRA), która w tych wyborach nie wystawiła kandydata i dodatkowo przeszła na prawą stronę sceny politycznej (Pietraszczyk-Sękowska, 2014). Po drugie do sukcesu ludzi powiązanych z siłami zbrojnymi przyczynił się brak charyzmatycznych cywilnych liderów. Partie prawicowe zmuszone były do szukania kandydatów w koszarach. Ekwadorska prawica, nie znajdując lepszego rozwiązania, wystawiła w wyborach 2008 r. Lucio Gutierreza, zapominając o jego wstydliwej przeszłości (uwikłanie w zamachy) oraz o lewicowych poglądach i licznych atakach na oligarchię. Również prawica boliwijska, licząc na pokonanie Evo Moralesa, zdecydowała się postawić na wojskowego. Był nim kapitan w stanie spoczynku Manfred Reyes Villa, były prefekt Cochabamby i niegdyś kandydat w wyborach prezydenckich (Montecinos, 2010). Warto nadmienić, że wysokiej popularności wojskowych sprzyjała obecność sił zbrojnych w najdalszych zakątkach kraju. Na prowincji siły zbrojne były często jedyną reprezentacją państwa, a realizując misje rozwojowe, przyczyniały się do wzrostu popularności konkretnych polityków, a ci chętnie wykorzystują żołnierzy do prowadzenia kampanii w terenie, co dało się zaobserwować w Peru w okresie rządów Alberto Fujimoriego, a także w Gwatemali po 1996 r., ale przede wszystkim w Wenezueli, Boliwii i Ekwadoru w okresie rewolucji boliwariańskiej (Norden, 2014; Pion-Berlin, Martinez, 2017). Po trzecie ważnym czynnikiem sprzyjającym pojawianiu się wojskowych na scenie politycznej okazał się być kryzys bezpieczeństwa i potrzeba silnego przywództwa - prezydenta rządzącego „twardą ręką”, gotowego na podjęcie radykalnych kroków dla dobra obywateli. 


\section{MILITARYZACJA PARTII POLITYCZNYCH W AMERYCE ŁACIŃSKIEJ}

Partie polityczne zakładane w ostatnich latach przez wojskowych odgrywają wiodące role na krajowych scenach politycznych. Chociaż rząd Lucio Guteirreza upadł w 2005 r. pod naporem protestów społecznych, partia, którą założył Sociedad Patriotica (PSP) - pozostaje drugą siłą na ekwadorskiej scenie politycznej. Poza tym warto odnotować w tym miejscu, że obecność wojskowych w polityce w Ekwadorze nie ogranicza się do samego Lucio Gutierreza. Inni wojskowi, tacy jak Paco Moncayo (alkad Quito od 2000 r., deputowany w Zgromadzeniu Narodowym w latach 2009-2013), gen. Jose Gallardo (kandydat Movimiento Unión Cívica Independiente w wyborach prezydenckich 1996 r., a później minister obrony) i płk Luis Fernandez, pozostają wpływowymi figurami na scenie politycznej (Montecinos, 2010). W Paragwaju Lino Oviedo stworzył trzecią siłę polityczną - Unión Nacional de Ciudadanos Eticos (UNACE).

W Ameryce Środkowej fenomen militaryzacji partii politycznych jest również obecny. W mojej ocenie najsilniej zmilitaryzowana jest gwatemalska scena polityczna, na której można wskazać kilka partii, w których główną rolę odrywają wojskowi. FRG, partia założona przez gen. Riosa Montta, do 2013 r. była jedną z kluczowych partii politycznych w Gwatemali. Obecnie funkcjonuje pod nową nazwą PRI, ale pozostaje powiązana ze środowiskiem wojskowych. Dodatkowo w 2002 r. na scenę polityczną wkroczył gen. Otto Perez Molina ze swoją Partido Patriota (PPG). Dziś pierwszą siłą polityczną (prawie $24 \%$ głosów w wyborach 2015 r.) jest nacjonalistyczna Frente de Convergencia Nacional (FCN), założona w 2004 r. przez grupę weteranów wojennych domagających się rehabilitacji i uznania zasług w konflikcie po niesłusznych (ich zdaniem) oskarżeniach o łamanie praw człowieka, wysuwanych przez członków rodzin zamordowanych i zaginionych (Elías, 2015). Wspierany przez nią kandydat, Jimmy Morales, wygrał wybory prezydenckie w $2015 \mathrm{r}$. z poparciem 65,48\% (Martinez, 2015). Ze sprawozdania przedłożonego krajowemu Trybunałowi Wyborczemu wynika, że partia w 37\% finansowana jest przez byłych i obecnych wojskowych (Villatoro, 2015). Trzon partii stanowią wojskowi, którzy kierowali kampanią antywywrotową w okresie dyktatury wojskowej i po jej formalnym zakończeniu w $1996 \mathrm{r}$. W pierwszym szeregu partii stoją m.in.: ppłk. Edgar Justino Ovalle Maldonado, gen. Luis Miranda Trejo, gen. Cesar Cabrera Mejia (szef wywiadu G-2 w okresie rządów Vinicio Cerezo Arevalo, doradca ministra zdrowia w gabinecie Pereza Moliny), kpt. Gregorio Augusto Lopez Gonzales (członek Narodowego Komitetu 
Wykonawczego FCN), gen. Quilo Ayuso (obecnie sekretarz partii). Co interesujące, na członkach kierownictwa partii ciążą poważne zarzuty łamania praw człowieka w okresie wojny domowej (1960-1996). Tuż przed wyborami w 2015 r. 18 członków partii, byłych wojskowych, zostało aresztowanych i przekazanych do dyspozycji trybunałów za poważne naruszenia praw człowieka. Stanowisko deputowanego i przysługujący mu immunitet uchroniły przed aresztowaniem czołowego polityka, jednego z założycieli partii, płk. Edgara Ovalle Maldonado, przeciwko któremu prokuratura wszczęła procedurę pozbawiania immunitetu.

Według Montecinosa (2010) udział emerytowanych żołnierzy w partiach politycznych w poszczególnych krajach jest zróżnicowany. Oznacza to, że nie we wszystkich formacjach politycznych udział wojskowych jest znaczący, zarówno na poziomie kierowniczym, jak i szeregowych członków. W PNP i UNACE tylko lider i nieliczne osoby z kierownictwa mają za sobą karierę wojskową. W Partido Socialista Unido de Venezuela (PSUV) oraz FRG i PPG w Gwatemali wojskowych jest znacznie więcej, ale też nie stanowią oni większości. W ekwadorskiej PSP niemal całe kierownictwo tworzą wojskowi, ale na poziomie szeregowych członków ich udział jest znikomy. Zdecydowanie najwięcej wojskowych członków (do czasu aresztowań) liczyła gwatemalska FCN. Niezależnie od liczby wojskowych w stanie spoczynku w szeregach poszczególnych partii wszystkie zmilitaryzowane formacje polityczne charakteryzuje organizacja na wzór armii. Spośród innych partii politycznych wyróżnia je silna hierarchiczna struktura organizacyjna i wodzostwo. Ruch etnokaserystyczny w Peru jest zorganizowany w oparciu o dowództwa narodowe. PSUV podczas wyborów zorganizowany jest w oparciu o bataliony, szwadrony, oddziały i jednostki walki wyborczej. Pełnię władzy w partii posiada wódz, który kieruje partią de facto w sposób autorytarny. Poza tym w kampaniach wyborczych często pojawiają się odwołania do walki. Wydaje się oczywiste, że osoby wychowywane od najmłodszych lat w duchu dyscypliny starają się przenieść sposób organizacji na tworzone przez siebie formacje polityczne.

Montecinos (2010) dzieli zmilitaryzowane partie polityczne w Ameryce Łacińskiej na kilka nurtów: lewicowy i antyliberalny (Hugo Chavez), lewicowy nacjonalistyczny (Humala), prawicowy populizm (FRG, FCN). Niezależnie od tego, czy są to formacje sytuujące się w środku bądź po lewej lub prawej stronie sceny politycznej, zawsze mają charakter nacjonalistyczny. Stoją na straży integralności państwa i narodu. Stąd taki zdecydowany sprzeciw wobec prób wydzielenia się Półksiężyca w Boliwii, Guayaquil w Ekwadorze, Zulia w Wenezueli czy autonomii ludów tubylczych w Gwatemali. 


\section{PODSUMOWANIE}

Kryzys demokracji w państwach latynoamerykańskich wyrażający się znaczącym spadkiem zaufania obywateli do państwa, jego instytucji i przedstawicieli oraz narastająca frustracja i rozczarowanie z powodu sytuacji gospodarczej, jak również powszechne w społeczeństwach poczucie zagrożenia ze strony grup przestępczych i formacji paramilitarnych (szwadronów śmierci), stworzyły dogodne warunki najpierw dla utrzymania przez armię silnej pozycji i rozszerzenia sfery wpływów, a następnie powrotu do władzy, tym razem w drodze demokratycznych wyborów. Szerokie warstwy społeczeństwa rozczarowane neoliberalnymi rządami cywilnych polityków, którzy przez lata w żaden sposób nie przyczynili się do poprawy ich sytuacji ekonomicznej i którzy nie zdołali powstrzymać narastającej fali przemocy, zwróciły się w stronę „polityków w mundurach”, proponujących w jednych krajach rewolucyjne zmiany społeczno-gospodarcze i polityczne (Wenezuela), a w innych rządy „twardej ręki” (Gwatemala) w trudnych i niebezpiecznych czasach. Obywatele państw Ameryki Łacińskiej zgodzili się de facto na ograniczenie demokracji (wprowadzenie demokracji ludowej) w imię inkluzji społecznej, zmniejszania nierówności społecznych i zwiększenia bezpieczeństwa.

Militaryzację polityki w Ameryce Łacińskiej zwykło tłumaczyć się niestabilnością demokracji, historycznie ugruntowaną rolą wojska, niestabilnością i niewydolnością instytucji politycznych, kryzysem reprezentacji oraz zaufania obywateli do państwa i jego instytucji. Faktem jest, że im bardziej rozwinięta jest kultura polityczna, wyrażająca się wysokim poziomem legitymizacji władzy, istnieniem konsensusu co do procedur przekazywania i przejmowania władzy, wysokim poziomem zaufania społecznego, sprawnym działaniem instytucji publicznych, niskim poziomem korupcji oraz istnieniem społeczeństwa obywatelskiego, tym mniejsze możliwości dla interwencji wojska. W państwach, w których demokracja cieszy się większym poparciem (Urugwaj, Argentyna, Chile oraz Panama), wojskowi są niemal nieobecni w polityce. Natomiast w państwach, w których poparcie dla demokracji jest słabsze (Peru, Paragwaj, Gwatemala, Honduras), udział wojskowych w polityce jest znaczący. Bez wątpienia aktywność wojskowych w polityce skorelowana jest również ze społecznym poparciem dla zamachu stanu. Im wyższa akceptacja społeczna dla pozoakonstytucyjnych działań sił zbrojnych - a ta jest w Ameryce Łacińskiej bardzo wysoka - tym większa obecność wojskowych w polityce. Wzrost pozycji i roli sił zbrojnych umożliwia niedostateczną instytucjonalną kontrolę demokratyczną nad siłami 
zbrojnymi, a z drugiej strony poszerzanie zakresu kompetencji wojska o zadania rozwojowe, ale głównie te związane z bezpieczeństwem.

Podsumowując rozważania dotyczące militaryzacji polityki i udziału wojskowych w polityce w Ameryce Łacińskiej, skłaniam się do sformułowania następujących wniosków. Po pierwsze większość wojskowych zaakceptowała demokrację elektoralną jako ,jedyną grę w mieście” (Alfred Stepan i Juan Linz), w której wybory są jedyną drogą zdobywania i legitymizowania władzy. Po drugie wojskowi dążą dzisiaj raczej do umocnienia swojej pozycji przy demokratycznych rządach niż do ich obalania. Po trzecie siły zbrojne zaakceptowały władzę cywilną i demokrację warunkowo, zapewniając sobie jednocześnie szeroki zakres autonomii, która ostatecznie uniemożliwia konsolidację słabych i młodych demokracji latynoamerykańskich. Co prawda zakończyła się era rządów wojskowych i wojskowych zamachów stanu, ale nie jest to równoznaczne z końcem militaryzmu i interwencji sił zbrojnych i wojskowych w sprawy polityczne i społeczne w Ameryce Łacińskiej.

\section{BibliogRAFiA:}

Arevalo de Leon, B. (2008). Un problema de Estado. Limites y retos a la subordinación militar en Guatemala. Nueva Sociedad, 213 (enero-febrero), 112-127.

Booth, J.,Wade, C., Walker, T. (2014). Understanding Central America. Global Forces, Rebellion and Change. Philadelphia: Westview Press.

Cálix, A. (2010). Honduras: de la crisis política al surgimiento de un nuevo actor social. Nueva Sociedad, 226 (marzo-abril), 31-54.

Donadio, M. (2003). Las relaciones civico-militares y la construción de instituciones en America Latina: enfrentando la crisis de las jóvenes democracias. Pobrane z: http:// www.resdal.org/Archivo/d00001a3.htm.

Elías, J. (2015). Guatemala elige presidente este domingo en medio de gran crisis. El País. Pobrane z: https://elpais.com/internacional/2015/10/22/america/1445525679_278701. html.

Kruijt, D. (2012). Las fuerzas armadas en América Latina, antes y hoy. Ciencia politica, 14 (julio-diciembre), s. 95-112.

Kruijt, D., Koonings, K. (2002). Fuerzas Armadas y política en América Latina: perspectivas futuras. Iberoamericana, II, 8, 7-22. Pobrane z: http://www.iai.spk-berlin.de/ fileadmin/dokumentenbibliothek/Iberoamericana//08-kruijt-koonings.pdf.

Kohn, R. (1997). The Forgotten Fundamentals of Civilian Control of the Military in Democratic Government. Papers of the Project on U.S. Post-Cold War Civil-Military Relations. John M. Olin Institute for Strategic Studies. Cambridge: Harvard University.

Larsen, E. (2004). Civil - Military Relations: Continuity or Change? A Comparative Analysis of El Salvador, Guatemala and Honduras. Thesis Submitted for the Degree. Bergen: University of Bergen. 
Latinobarometro. (2017). Informe 2017. Buenos Aires. Pobrane z: file://C:/Users/user/ Downloads/F00006433-InfLatinobarometro2017.pdf.

Manaut, R., Sotomayor, A. (2008). El dilema mesoamericano: la inseguridad externa y la vulnerabilidad intrna. W: R. Lagos (red.). America Latina: integración o fragmentación? (s. 387-419). Buenos Aires: Edhasa.

Martinez, J. (2015). El cómico Jimmy Morales, elegido presidente de Guatemala. El País. Pobrane z: https://elpais.com/internacional/2015/10/26/actualidad/144 5824124_082191.html.

Montecinos, F. (2010). Politicos de verdeolivoApuntessobre el militarismolatinoamericanoy suinfluenciapolíticaen las últimasdécadas. RevistaAustral de CienciasSociales, $18,107-119$.

Norden, D. (2014). Democratizing Revolutionary Soldiers: Politicized Militaries and Democratic Transitions in Latin America. Buenos Aires: FLACSO. Pobrane z: http:// web.isanet.org/Web/Conferences/FLACSOISA\%20BuenosAires\%202014/Archive/ a055fe8a-6ea4-47e5-b373-3347c4cd72dc.pdf.

Pietraszczyk-Sękowska, J. (2014). Ollanta Humala na scenie politycznej Peru - transformacja programu politycznego, społeczeństwa czy państwa? W: K. Krzywica (red.). Transformacje demokratyczne $w$ Ameryce Łacińskiej: problemy - wyzwania - implikacje (s. 79-11). Lublin: Wydawnictwo UMCS.

Pion-Berlin, D. (2019). A New Civil-Military Pragmatism in Latin America. Pobrane z: http://www.fesseguridadregional.org/images/stories/docs/0888-001_g.pdf.

Pion-Berlin, D. (2008a). Militares y democraciaen nuevo siglo. Nueva Sociedad, 213 (enero-febrero). Pobrane z: http://www.academia.edu/2867830/Militares_y_democracia_en_el_nuevo_siglo.

Pion-Berlin, D. (2008b). Unexpected Civil-Military Relations in $21^{\text {st }}$ Century Latin America. Nueva Sociedad, 213 (enero-febrero). Pobrane z: http://nuso.org/media/ articles/downloads/3493_2.pdf.

Pion-Berlin, D., Martinez, R. (2017). Soldiers, Politicians, and Civilians. Reforming Civil-Military Relations in Democratic Latin America. Cambridge: Cambridge University Press.

Sotomayor, A. (2006). Diagnostico de las relaciones civico-militares en America Latina: Avances y retrocesos en materia de politica de defensa. CIDE.

Stelmach, M. (2016). Wojsko a demokracja w Gwatemali. Pozycja i rola sił zbrojnych w Gwatemali w okresie rządów gen. Otto Pereza Moliny. W: K. Kamińska-Korolczuk, M. Mielewczyk, R. Ożarowski (red.). Systemy polityczne i komunikowanie polityczne w Europie i na świecie (s. 226-267). Gdańsk: Uniwersytet Gdański.

Velazquez, A. (2008). Fuerzas Armadas y gobiernos de izquierdaen América Latina. Nueva Sociedad, 2013 (enero-febrero), 80-94. Pobrane z: http://nuso.org/articulo/fuerzasarmadas-y-gobiernos-de-izquierda-en-america-latina/.

Villatoro, D. (2015). Los militares que financian Jimmy Morales. Plaza Publica. Pobrane z: https://www.plazapublica.com.gt/content/los-militares-que-financian-jimmy-morales. 